Published in D. Tannen (Ed),1990 Special issue of Discourse Processes, pp. 123-141. Reprinted in D. Tannen (Ed), 1993 Gender and conversational interaction 13, Oxford University Press.

\title{
6 \\ Gender, Politeness, and Confrontation in Tenejapa
}

\author{
PENELOPE BROWN
}

This chapter examines some interactional details of a court casc that took place in the Mexican community of Tenejapa, a community of peasant Mayan Indians who speak a language called Tzeltal, and compares it with Tzeltal verbal interaction in other contexts. In particular I want to contrast women's speaking style in amicable cooperative 'ordinary' Tzeltal conversation with their specch in angry confrontation in a Tzeltal court casc, the only context in this socicty in which face-to-face angry confrontation is authorized for women.

The purpose of this study is to explore how relations between language and gender are context dependent, with respect to both the kind of discourse-in this case cooperative versus confrontational interactionand the speech event and the particular norms governing talk within it. Yet, despite this context dependency, women's characteristic concerns, and the ways of speaking characteristic of women in this socicty that derive from those concerns, put their stamp on interactions with radically different interactional goals, so that gender is, in some senses, a "master status" transcending contexts in this society.

Specifically, what I want to claim is that, in many ways, the interactional conduct of a Tzeltal court casc, a formal arcna for face-to-face confrontation with the aim of settling disputes between people, is the inverse of interactional conduct in ordinary conversation in Tencjapan socicty. That is, ordinary conversational structures and interactional norms are systematically violated in a public display of indignation and anger. Nevertheless, in this context, certain features pervasive in women's speech in ordinary 
amicable conversation-features used to convey positive affect, empathy, agreement, sympathetic understanding - are here carricd over but are used to convey the opposite: negative affect, hostility, contradiction.

In short, even when women aren't being polite-cmphatically the opposite-their characteristically femalc "ways of putting things" indirectly, using irony and rhetorical questions for positive politeness, carry over but with inverted functions: to emphatically contradict or disagree.

In what follows I first give a brief indication of some current issues in language and gender research to which this study is oriented. Second, I describe conversational structures employed in ordinary Tzeltal conversation, as well as the norms governing Tzeltal interaction in general and women's normal public demcanor in particular. Third, I describc the organization of Tzcltal court cases and show how interaction in the courtroom flouts certain of these norms systematically. Finally, I draw some conclusions about (1) the nature of dispute scttlement in Tencjapa, (2) how gender meanings can get transformed in different contexts, and (3) implications for language and gender rescarch in other contexts and socictics.

\section{Current Themes in Language and Gender Research}

Out of the past fifteen years of cross-linguistic and cross-cultural rescarch into aspects of the relationship between language and gender has gradually cmerged the perspective into which I want to place the data discussed in this chapter. This perspectivc, which has been promoted in my own work (Brown 1979, 1980, Brown \& Levinson 1979, 1987) and more recently cogently argued for in, for example, McConnell-Ginet (1988), Philips, Stecle, and Tanz (1987), and Ochs (1992), has scveral basic tenets:

1. Although gender-based differences in language arc, for most languages examined to date, fairly minimal in language structure, they arc pervasive in language use, cspecially in clusters of linguistic features that differentiate male and female communicative styles.

2. For the most part, gender is not marked directly, but gender indexing is indirect, via other connections between gender and habitual uscs of language (specch acts, specch cvents, social activitics, interactional goals, and strategies).

3. Gender indexing is context dependent in very interesting, patterned ways.

In this view, the study of language and gender is part of the more general study of relations between language and social meaning (Ochs 1992). We have to think in terms of a complex web of social meanings being conveyed when individuals speak, gender being only onc, and not necessarily always a relevant onc, of thesc social meanings.

What is needed is a much better understanding of both gender, as a social attribute, and how social meanings like gender are expressed in speech. What kind of a thing is gender? Is it a master status, omnirclevant 
in all situations? How is it related to social roles, to activities and speech events? 'To what extent do gender norms constrain people's behavior even in situations in which gender should be irrelevant? How do different social meanings (for example, professional identity versus gender identity) interact? How do these reflect speakers' perceptions of their social relationships?

The study reported here is oriented to these sorts of questions; it aims to illustrate with an example from my own work in southern Mexico what I think is a profitable approach to the problem of trying to understand the ways in which gender influences language use and is reflected in that use. To the extent that gender influences the social meanings that people express when they speak, these can be discovered by conversation-analytic techniques applied to interactions in different social contexts, where language is being used to achieve different purposes.

This paper takes up this banner in one particular domain, comparing gender influenes on language usage in casual cooperative conversation with those in angry confrontation. The Tzeltal case cxemplifics the approach originally promoted by Garfinkel (1967): If you want to understand social norms, look at how they are breached and how the management of breaches reinstates the norms. ${ }^{1}$

\section{Ethnographic Background}

Tenejapa is a peasant Mayan community in the Chiapas highlands of southern Mexico, about twenty miles from the town of San Cristóbal de las Casas. It is a corporate community of Tzeltal-speaking Indians, in a populous rural area where there are many other Indian communities of Tzeltal or Tzotzil speakers, each of which maintains a strong ethnic identity distinguishing it from the others and from the dominant Ladino (Mexican national) culturc.

As a corporate community Tencjapa has its own hicrarchy of civilreligious officials who run the local political system with a large degree of autonomy, although it is subject to the Mexican laws and policies in some arenas (schooling and health, principally). In law Tenejapa can settle its own disputes, except for very serious ones such as murder, which go to the Mexican court in San Cristóbal.

The community consists of dispersed hamlets, connected by a dense network of foot trails, and a ceremonial center, where local political and religious ceremonies are based and where people holding political or religious offices live during their tenure. Here there are a large church, the locus of the community's religious ceremonies, and a town hall (Cabildo), which is the locus of political activities; it is here that our court case takes place.

\section{Norms of Interaction}

My 1972-1973 fieldwork in Tenejapa focused on gender differentiation in this community in narticular male-female stvles of interaction (Brown 
$1979,1980)$. In this work it became clear that, on many indices, women can be seen to be "more polite" than men; men are more direct and straightforward in their speech. Thus, compared with men, women are more positively polite to intimates and familiars, expending more interactional effort in reassuring thcir interlocutors of their interest in, and appreciation of, their conversational contributions. They are also more ncgatively polite in public, where they are normally self-annihilating kinesically and operate under very stringent interactional constraints including strong inhibitions against public displays of emotion or public confrontation, which do not apply to nearly such an extent for men. Self-control and self-humbling are crucial aspects of a woman's public presentation of self; sanctions against behaving otherwise include ridicule by one's peers and potential physical punishment by fathers, elder brothers, or husbands.

Women's demcanor in public is highly constrained; cye contact tends to be avoided, and deference to or social distance from unfamiliars is indicated by using a very high-pitched register. Among familiars, "positive

politencss" imbucs most interaction with claboratcd cxpressions of sympa4hy, approval, and interest. Rhetorical questions and ironics are a conventionalized mode of expression among women. They are used to stress shared understandings and values, emphatic empathy and agreement, as in these two examples taken from natural conversation in relaxed situations. ${ }^{2}$

1 A: . . mak ma wan sc'ahubotik ta stamel 'in c'i

... perhaps it's not possibly that we get tired from bending over to pick (coffee, that has fallen to the ground) then! (conveys sympathetic understanding: of course, it's tiring!)

B: mak bi yu'uni ma sc'ahub.

Perhaps why don't (we) get tired. (conveys: We sure do!)

A: yak mak.

Yes, perhaps. (We do!)

2 A: mak ban ya'wil Papba

Perhaps where do we see each other?

(conveys: Nowhere, we never get a chance to see one another.)

B: hu?u

No (agrees with implicature: No, nowhere.)

Women use this form of expression notably more than men do; indeed, it seems to be a highly conventionalized form of feminine positive politeness in this society (see Brown 1979:chap. 4, and Brown, in press, for more details).

\section{Casual Conversational Style}

Tzeital conversation is archetypally two-party, with speaker and respondent roles distinguished. Turn-taking rules apply quite rigidly; overlap is relatively rare and covers relatively short segments of the utterance at speaker-transition points. The floor is passed back and forth at regular 
short intervals, and interruptions are relatively few. Even during the telling of a story or anecdote (where one interlocutor has all the information and is trying to impart it to the other), the respondent takes up each point with a response indicating interest, understanding, an appropriate cmotional reaction, or simply the Tzeltal equivalent of "yeah, I hear you, go on." These, essentially back channel, comments occupy a full turn; they normally do not overlap with the storyteller's running speech as they often do in English conversations. Smiles, nods, or other nonverbal attempts to respond might accompany, but cannot supplant, a verbal response.

These responses often take the form of repeating part of the prior speaker's utterance, elaborated with appropriate prosodic indications of surprise, interest, or agreement. These repetitions structure Tzeltal conversations into neat little sequences of utterance, plus repeat-response, plus optional repcat of the repeat (or part of it), and so on, resulting in interchanges like the following, which illustrates this highly characteristic structure of Tzcltal conversation:

3 (from a conversation between an elderly woman (GM) and her visiting granddaughter (GD), who is explaining how it is that she has come visiring so late in the day)

GD: ha?te ha? ye z'in 'a ka'yix tal ha?al ho'otike

But so it was, we-excl. got rained on (on the way here)

GM: ch! la ${ }^{2}$ wa'yix tal $z^{\prime}$ in

Oh! you got (rained on) then

GD: la!

GM: la ha? in sab $i$

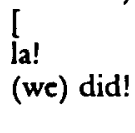

That was this morning.

GD: ha?

It was.

GM: ha?

It was.

GD: ha?

It was.

GM: ha'te hic suhtat nix tal $\mathrm{Pa}_{\mathrm{a}}$ 'in

But so thus you've just returned (from hot country) then.

GD: suht nix $z^{\prime}$ in

So (we) have just returned.

GM: suht

Returned.

GD: suht

Returned.

The conversational uses of such repeats as responses to an utterance have been reported for other languages and societies (see, for example, Tannen 1987, 1989, for English; Haverkate 1989:402 for Spanish), but in Tzeltal these are conventionalized as the normal way to respond to an interlocutor's narrating or explaining something. Men in Tenejapa do this too, in casual speech, but their repeat cycles tend in general to be shorter and less affectively positively polite. 


\section{Arenas for Conflict}

Women in daily interaction tend to suppress conflict. It is veiled, even in private, and, between nonintimate women, openly angry confrontation rarcly occurs. Interaction is simply avoided, and gossip, mockery, and backbiting against the object of onc's anger are expressed to sympatheric intimates.

Anger between women who are intimates (for example, members of one's own household, family, or neighbors) is normally expressed through controlled "leakage," in which silence, nonresponsiveness, or terse replies (clipped pronunciation and abrupt timing) to proffered utterances can indicate restrained anger. There might also be kincsic distancing, avoidance of smiling, of eyc contact, and of physical contact, which contrast with normal relaxed behavior to suggest anger. It is common to declare stiffly, if questioned, that one is not angry, to insist that nothing is wrong, and, if pressed, to launch into a tirade of self-abuse, saying, in effect, "I'm a terrible person, a no-good, a bum." In this context it is overwhelmingly obvious that the person is angry, but there are strong constraints on overtly admitting it to the object of onc's anger. ${ }^{3}$

$\mathrm{Men}$, in contrast, can and do express conflice overtly in relativcly private contexts; both verbal and physical abuse from husband to wife are routine in some houscholds. In public arcnas men are likely to express open conflict only if drunk. $r$ in er cors

Procedures for dispute settlement operate at various levels. They might be worked out through family mediation or taken up in front of a local hamlet arbitrator, in informal meetings with the two sides both presenting their points of view; the arbitrator (a schoolmaster or church leader, for example) has, however, no authority to impose a settlement.

The forum of last resort for irresolvable conflicts is the Tenejapan court; this is resisted by most, as here private quarrels (and their cmbarrassing or humiliating details) arc exposed to public vicw. That is what happened in the case we're going to examine here.

\section{A Tenejapan Court Case}

\section{Format and Procedures}

The format of a typical court case at this community level is a hearing in the Cabildo, presided over by the Tenejapan president or judge, either of whom can act as judge for the casc. The "plaintiff" (the person who originated the case with a complaint to the judge) and the "defendant" (the accused party, who has been summoned to the court) appear, and each is given a chance to present his or her casc. ${ }^{4}$ This is done in a special named speech style, (col k'op "explaining speech"), which is a sequential presentation of argument (with features similar to those of narrative in casual conversation) laying out the source and details of the dispute from 
the speaker's point of view. ${ }^{5} \mathrm{~A}$ number of Tenejapan officials who have an interest in the case, or who have nothing else to do, may be present as audience to the transaction, though they rarely participate. The judge presides, listens, asks questions, and eventually decides what ruling to make. This ruling is discussed, and may be modified, until all participants agree to it. Then it is typed up by the Ladino secretary in an official document (an acta), which is signed by all three; copies are retained by each participant and a copy goes into the court record.

This process is set in motion by a complaint, when the plaintiff comes to the president or the judge, or to one of the officials representing the plaintiff's local hamlet, and asks for the defendant to be summoned to court. The officials representing the defendant's hamlet go to his or her house and fetch the defendant to the town, where a hearing takes place in the Cabildo (or at the president's house). Pcople who are afraid or ashamed to appear may get someone to appear for them-a representative who is deemed good at speaking in public. Friends of the court, family supporters, witnesses, and casual bystanders may all be present, may wander in and out, and may contribute to the discussion. Normally the defendant pays the fee exacted by the officials for the summons; in addition, fines or jail or a period of community service (for example, work on church repairs) might be imposed. In cases involving moral breaches, a lecture might be given to the wrongdoer by the judge. The procedure ends with the signing of the acta by all three parties.

The majority of issues tried in this forum are domestic quarrels, including adultery, physical violence such as wife-beating and drunken attacks, child support, divorce and property settlement. They can also involve land disputes and inheritance disagreements, debts, property damage or (rarely) theft, interactional hostilitics (drunken insults, character assassination), and witchcraft. 6

The procedure, then, is straightforward: When the opponent is not present in the courtroom (because he or she couldn't be found or is already in jail, for example), the plaintiff "cxplains" his or her complaint in a long narrative detailing the cause and conduct of the dispute. The judge asks questions, then makes a ruling. The tone of the court cases we observed with no opponent present was generally earnest, calm, and selfrighteous. When the opponent is present, however, as is normally the case, blatant interactional confrontation can occur between the two, in which the interaction violates, point by point, the interactional norms of cooperative discourse, resulting in a display of confrontation for rhetorical (and perhaps cathartic) ends.

\section{The Case of the Runaway Daughter-in-Law}

In the case we are considering here, a woman, the principal plaintiff, complains that her former daughter-in-law owes her a lot of money. The 
background of this complaint is as follows: The daughter-in-law married her son after a normal Tenejapan courtship, stayed with him in his parents' household for five months, then ran away and married another Tenejapan man without any divorce proceedings first. This breach of social relations, outrageous by Tenejapan standards, is not the subject of this case, however; in fact it only comes up obliquely in the forty minutes of the proceedings. The complaint is that the daughter-in-law, while living with her first husband's family, received a number of gifts from her husband and his parents. These gifts were things normally (but not obligatorily) given to new brides and included a corn-grinding machine, a skirt, a red belt, a white belt, some meat, and some thread for weaving. The plaintiff has no (official) complaint against this girl for leaving her husband, but she claims that she should be paid for all these items that were given to the bride, in good faith, as a ncw daughter-in-law.

The defendant plcading here isn't the wife who remarricd, but her mother. The daughter doesn't appear in court (she was too ashamed, because of her "bad" behavior, it was said). The claims are against her natal family, represented here by her mother.

The case takes place in the Cabildo, around a large central table. The judge is seated at one side; the litigants take up standing positions at the end near the door. The Ladino secretary is typing business letters (unrelated to this case) at the far end of the room. Around the table on benches against the wall are seated about ten Tenejapan officials and litigants from preceding cases, as well as a number of bystanders (plus the two ethnographers, filming and taping the event). The case begins when the judge addresses the plaintiff and asks her to explain her complaint (she has previously entered, greeted the judge, and stood waiting at the end of the table while another case was presented). The plaintiff presents her claims, and the defendant (the runaway wife's mother) vocifcrously argues against these claims. There is a lot of disagreement, simultaneous speech between the defendant and the plaintiff, and overt expression of hostility, anger, and contempt-quitc cxtraordinary by Tencjapan standards. The interaction alternates between sections in which the judge poses questions and the plaintiff or the defendant replies, in an orderly fashion, and those in which they take off in mutually oriented antagonistic tirades while the judge quietly listens. Eventually the judge succeeds in getting them to agree that the defendant will pay the plaintiff nine hundred pesos for the gifts and that she will bring the money to court the following Sunday. This solution represents a compromise between the amount of money the plaintiff claimed (totaling some twelve hundred pesos) and the amount the defendant concedes is due (somewhat less than nine hundred pesos), as well as in the amount of time she is given to come up with the money. The local official is paid for his summons by the defendant, and the case ends (to be followed immediately by another one) when the two women leave the courtroom. 


\section{Interaction in the Courtroom Context}

Here I focus on specific contrasts between courtroom behavior and ordinary interaction.

Speech Epent Demarcation. There are no clear boundaries to the event. Minimal greetings are given by the plaintiff, none by the defendant, and no farewells at all. And, although the case is started by the judge's saying to the plaintiff, "So I'll listen to your speech now ma'am," it is readily interrupted when he is called to attend to other business, and, although the two parties may carry on their presentation, the judge isn't listening. ${ }^{7}$

Participants. There are three main participants (plaintiff, defendant, and jutge), with a large audience of about ten officials and several litigants from other cases, including a number of men from the neighboring Indian community of Chamula. With this "audience" (or, more strictly, "copresent bystanders," not necessarily attending) under other circumstances the behavior of Tencjapan women would be extrencly circumspect. Members of the audience frequently engage in background conversation not addressed to the case at hand. Periodically the judge is drawn into this background conversation, especially when required to say ritual grectings or farewells to men who are entering or leaving the courtroom, but the litigants in our case ignore this entirely. ${ }^{8}$

Roles of speaker and addressec are fluid and rapidly switched, and the large degree of overlapping specch means that both the plaintiff and the defendant can be both speaker and addressee simultaneously. The judge's institutional role as adjudicator is operated with restraint; he docs not heavy-handedly push the partics toward a resolution but allows them to work toward one themselves with minimal interference. And his role as listener is not rigidly upheld; although some of the time he does conscientiously display his attentiveness with hms, uhuhs, and the like, at several points he turns to other business. The audience takes no part in the argument or discussion of this casc.

Although the judge is the monitor of the proceedings, except at the beginning when he invites the plaintiff to begin and asks her some questions, he rarely exercises his right to choose the next speaker. Generally, turn taking operates as a local management system, as in ordinary casual conversation.

Turn-Taking Structure. The most interesting features of the interaction are in the management of turn taking, which has two distinctive characteristics:

1. An overall dyadic structure is imposed on what is, in principle, a three-party interaction.

2. Periodically the normal turn-taking rules are suspended in interaction between the two women, and they speak simultancously. 
First, despite the fact that there are threc main participants, the interaction overwhelmingly displays a dyadic structure, with two of the three participants addressing one another (in an A-B-A-B-A-B sequential structurc). The third party frequently trics to gain the floor and participate in the dialogue but cither fails entircly (is ignored by the two) or succeeds in gaining only one addressec, and the dyadic structure is retained with different members constituting the dyad. Thus, over the entire event, specch alternates among the judge-plaintiff dyad, the plaintiff-defendant dyad, and the judge-defendant dyad.

Speech in ordinary conversation also shows a marked tendency toward dyadic exchanges, but the clearly demarcated roles of speaker and respondent, with the respondent replying with encouraging repetitions of the speaker's utterances, is almost entirely absent in the courtroom.

The most surprising featurc of this interaction, compared with specch in other contexts, is the simultancous specch of the plaintiff and the defendant for extended periods. As a result of persistent attempts to gain the floor by the party not included in the dyad of the moment, there are frequent intermptions and a great deal of overlap, which in extreme instances consists of the plaintiff and the defendant speaking simultancously at one another for as much as half a minute. Sometimes thcir utterances, though heavily overlapping, are responding to one another's remarks and challenges; at other times they are apparently totally independent tirades.

Thus, the basic dyadic structure of the interaction is continually being challenged by the party Ieft out at any moment, but the successful challenge only succeeds in shifting the constitution of the dyad. Interactional orderliness is also maintained to some degree by the judge exercising his monitoring role; periodically he interjects questions to break up a dyadic interchange and redirect the topic. Frequently, however, his attempts fail, as illustrated in (4), where the judge makes two unsuccessful tries beforc finally capturing P's attention (at linc 324) on his third attempt $(\rightarrow$ marks turns where J tries to enter the conversation):

4 Judge's attempts to monitor

( $\mathrm{D}=$ defendant $P=$ plaintiff $J=$ Judge)

( $P$ is in the middle of her explanation to J about the background to her claims against $D$ )

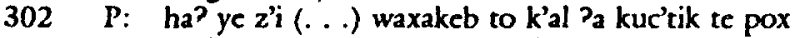

So it was for 8 days we drank the booze together

$\begin{array}{ll}303 \rightarrow \mathrm{J}: & \text { bweno } \\ & \text { OK, }\end{array}$

$304 \mathrm{~J}:$

ha' nax bal ?a z'i bi =

305 (J) =yu? me ya?

That was how it was, eh?

306 D: because if you- 
307 (D)

308 P: $\quad$ ha? (.) waxakeb k'al गa kuc' ho?tik ?a poxe (.)

peru bi yu'un ha? nax ya'toy Pa'ba

but why is it you just pride yourself

(to D) It is so. For 8 days we drank the booze that time,

309 (P) (ba kuzi) k'amal ba ya slekot $z^{\prime}$ in te $=$

? where it was made good then, at

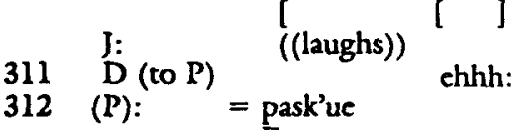

$313 \rightarrow \mathrm{J}:$

Easter

[ ]

yu? nax z'i ha? nax bal z'i ya stikun te-

Just because, so is it just that he sent-

$314 \mathrm{D}$ (to P)

315 (D) mac'a xkucoh ?ocel (tcklum) (.) who had carried (it) entering town?

316 (D) tatik ya- Pa scelbet Pa Pba mac'a $P_{a}$ skucoh (...)= the man, he ?-ed for you, the one who had carried

$317 \quad$ P:

[] mac'a lah: (.)

Who, was it said

318 P:

Huh.

319 (D): =pepsi $\mathrm{Ce}=$ the Pepsis, eh?!

$320 \mathrm{~J}:$ hoo

321 P: $\quad=$ ha? bal z'i kerem ku?

(to D) Was it my own boy then?

$322 \rightarrow \mathrm{J}:=$ ya na wan z'i stolik Pin te pox c'c They perhaps paid for this booze then, ch?!

323 D (to P); xk'otok (cikin) bi mak

324 P (to J); hai? mak ha? z'i kerem ku?un Perhaps it was my boy, ch

325 J: ya wan Pa (st- kurik na) Perhaps he (?) His (ear?) returned perhaps, elh?

326 P: $\quad$ ma niwan $s$ os stikun bel Pa huc stukel= 327 (P) Perhaps he didn't send away (for it)
327 (P) =ya'wa'y $z^{\prime}$ in pox yan $z^{\prime}$ in te ha? nax kalat.... you see then, the booze, or rather it's just as I tell you,
328 J: hoo

( $P$ continues her explanation to $\mathrm{J}$ )

This refusal to yield the floor is extremely marked behavior by two women to a male official; he, however, treats the interchanges as a normal and 
The simultaneous speech of the women and their refusal to yield the floor are important vehicles for their expression of antagonism. The mood of dynamic confrontation that permeates this interaction is also carried more explicitly by their aggressive kinesics, direct cyc contact, and aggressive gestures that suggest contempt or disgust. Occasionally there are overt insults and abusive words, but prosodic indication of anger and emphasis is rampant throughout.

In short, interactional antagonism is carried to a large extent in breakdowns and manipulations of the turn-taking rules: in interruptions, overlaps, and speech that is simultancous and nonresponding. In contrast, the plaintiff's and defendant's interchanges with the judge are much more orderly and slow, with fewer overlaps and interruptions. Both the plaintiff and the defendant occasionally use the Tzcltal "respect voice" (very high pitch) to the judge, though never to cach other.

Irony and Rhetorical Questions. A final rcalm for the display of antagonism is in the very noticeable absence of preference for agrecment; indecd, in direct contradictions of one another's claims, especially via an exploitation of women's typical positive politencss agrecment stratcgy-rhctorical questions and ironies-which are here donc sarcastically, as challenges. Let's look at some of these in detail.

5 Irony and rhetorical questions as confrontation

( $P$ has been listing her claims; / has just said "wait a minute" and begun to write them down, one by one).

231 J: te: $u m=$

the, um

232 P: $\quad=$ hm umhm

$233 \quad(1.5)$

234 J: $\quad$ zckel z'i

(for the) skirt, then

235 P: $\quad$ hm (.) ox-cehp z'in zekele (1.5) ca?cchp cuhkilal $\mathrm{Hm}$, three hundred then for the skirt, two hundred for the belt.

$236 \rightarrow$ D: bi yu? $\quad$ un ma huk z'in mak yu? ma ho'winikuk (sti) $=$ Why wasn't it then, perhaps it wasn't one hundred or so (ironic: conveys: it was only worth 100 pesos)

237 (D) = mak bit'il ta? ya stoytik yu? mak ha? te sle bi xan ?ae how is it that they overstate (the price of the belt) because perhaps it's that she (P) is looking for something more (from $m e$ )! (1)

239 (D)

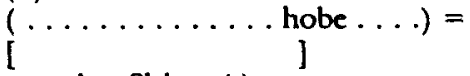

240 P: $\quad$ ya stak xa?leben (.)

You can look for (it- the belt) for me,

241 (P) ya stak xa?leben shol teme hice you can look for a replacement for it if that's the way it is. (i.e., if you think that was a cheap belt, get a better one!)

$242 \rightarrow$ D: $\quad=$ ha? yu' wan ha? z'i baz'il szozil z'i mak ma ha?= It's that, perhaps it's that it's real wool then perhaps! (Conveys: It wasn't of real wool; i.e., it was cheap!) 
243 (D) $=\begin{aligned} \text { (tay z'in men) } \\ \text { (perhaps it's not then) }\end{aligned}$

[ ]

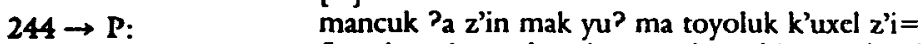

So what about that then, perhaps it's not that it was ex-

$245 \rightarrow$ D: $=$ toyol nanix stukel ?a $_{\mathrm{a}}$ 'i bi mak

pensive then (conveys: It was expensive!)

Really expensive, (it is) itself then, perhaps, eh? (conveys sarcasm: It was really cheap!)

The effectiveness of this ironic phrasing of agreement, sarcastic agreement, to convey disagreement relies on the conventional use of irony to agree, and the disagreement is thereby made more poignant, more dramatic, taking place as it does against the background of feminine positive politeness. By the same token, the occasional sarcastic use of normally respectful address forms underlines the women's hostile intent.

\section{Conclusion}

This Tzeital court casc is a paradigm cxample of verbal interaction in onc social context (a court casc) being played out in opposition to the norms for verbal interaction in another social context (everyday public interaction), in order (partially) to reinforce those first-context norms (appropriate gender behavior) and, as I now argue, where face is threatened, in order to restore face. For the case under discussion is indecd partly about money but largely about face, and personal reputation. In the buildup to this confrontation, appropriate female role behavior and affinal behavior have been grossly transgressed; both parties have been publicly shamed. The conduct of the court case is, to a large extent, oriented toward reinstating them in the community.

Two distinct things arc at issuc in this court casc:

1. A dispute about financial outlays, requiring a monetary settlement

2. Face, as implicated in female roles, especially in the female in-law relationships

In aid of the substantive dispute is the content of the argument in court, which is overtly about the rights and wrongs of financial outlays: whether they occurred, whether they legitimately were part of the marriage ceremonies or part of subsequent in-law relationship obligations, and, therefore, whether they should be reimbursed due to the breakdown of the in-law relationship. In aid of face-support is the whole style of the courtroom proceedings: the plaintiff's portrayal of innocent outrage, indicating a generalized message to the effect that "this person has so rent the social fabric that I'm justified in breaking the norms of propricty governing female behavior" (specifically, nonconfrontation). By successfully displaying her outrage, she (1) reestablishes her face, (2) influences the financial outcome of the case, and (3) gets cathartic release from long-term pent-up anger. The defendant, by responding with a display of innocent 
outrage, casts doubt on the authenticity of the plaintiff's outrage and gains certain concessions in the financial outcome.

In Tencjapa, then, despite the strong constraints against public displays of anger, therc is an institutionalized context (and mode) for confrontation: a dramatized outrage played against the backdrop of appropriate norms for female behavior. The very excessiveness of the hostility expressed suggests that, in Tenejapa, litigation involves a form of drama in which the litigants are given scope to dramatize their antagonism, to display their anger and outrage in direct facc-to-face confrontation, in ways almost unheard of in other contexts. The forum of the courtroom provides a frame for this display that makes it interactionally manageable; such open display of anger outside the courtroom would be, for women, unthinkably dangerous, provoking accusations of witchcraft. The protagonists here are brcaking the norms (in a controlled manner), in order to affirm the norms of appropriate femalc bchavior.

I do not mean to suggest that all women in Tencjapan court cases behave in this confrontational manner, nor that men never do, but only that in court such behavior is not only sanctioned but actually necessary to recstablish onc's besmirched reputation.

The courtroom solution results in a compromisc, negotiated between the two protagonists, that reinstates both in the community with some face left. Gossipers can now have a ficld day with the details of the disputc; nonetheless, by going through the court procedure the plaintiff reestablishes herself as "not exploited and shamed," and the defendant reestablishes herself as having paid for her daughter's flouting of social norms.

But here we find the paradox at the heart of Tzeltal litigation. If the display and revelation in the courtroom interaction accomplish the working out of anger and the reinstatement of public "face," at the same time they work against one of the most cherished Tencjapan values: selfprotcction through emphatic insistence on privacy. Privacy is an overwhelming concern in Tenejapan social life; in this small, gossip-ridden community people are cxtremcly sensitive to what others know about them, as well as to what they can learn, and infer, about others from their behavior. Hiding the details of one's personal effects and social relations from prying eyes is a dominant concern in interpersonal conduct. 9 In this context it is astonishing that cases are ever brought to court at all, and indecd, public cxposurc of one's private affairs in court is much feared. Litigation is a form of mutual punishment, at least potentially, through which the air is cleared. Face is saved by face being thrown to the winds.

That in a small-scale, face-to-face, nonhierarchical peasant society where privacy is a dominant concern disputes are settled in a confrontational display is perhaps not too surprising. And that they are likely not to remain settled is perhaps an obvious consequence of their agonistic display.

What can we conclude from all this about gender and language in Tenejapa? The norms of gender-appropriate behavior are clear: Politeness, 
restraint, and circumspection are enjoined. Nonetheless, in one kind of social context, litigation, whether at the local level or in the official Tenejapa court, where a woman's reputation is on the line inverted behavior occurs: Women are given license to excel in public demonstrations of anger and outrage. Indeed, such a display seems part of the very process of, and essential to, clearing one's stained reputation, reestablishing one's public face. 10

This provides clear evidence, for Tenejapan society, that gender is not a unified one-dimensional feature of one's social identity; one's gender has different applicability (and different effects) in different kinds of situations. We do find (in Tenejapan society, at any rate) gender-characteristic patterns of speaking across contexts-even contexts as contrastive as those we've been considering - that indicate that gender-specific "ways of putting things" can operate across contexts, and this is perhaps especially so when one's face qua woman (or man) is implicated in the different contexts.

In a recent paper, Elinor Ochs (1992) puts forward an analysis of how gender is indexed that can help us understand what is happening in Tenejapa. Ochs argues that the relation of language to gender is not a straightforward mapping of linguistic form onto the social meaning of gender but is constituted and mediated at least partly by the relation of language to what she calls stances: general interactional poses having to do with how one presents oneself to others, for example, hesitation/aggression, or coarseness/delicacy, or accommodation versus nonaccommodation to the addressee. I think that the ironies and rhetorical questions that proliferate in Tenejapan women's speech are manifesting a characteristic female stance, emphasizing in-group solidarity expressed through ironic agreement and displays of shared values; women's joking and humor in Tenejapa also often take the form of irony. In amicable interactions, women's positively polite ironic phraseology assumes and stresses shared values and norms, cooperation, mutual sympathy and understanding. In the courtroom confrontation this stance is cvoked, but from a distance, ironically, in the sarcastic politeness of hostile pseudoagreement.

As Ochs (1992:341-342) puts it,

the relation between language and gender is mediated and constituted through a web of socially organized pragmatic meanings. Knowledge of how language relates to gender is not a catalogue of correlations between particular linguistic forms and sex of speakers, referents, addressees and the like. Rather, such knowledge entails tacit understanding of 1) how particular linguistic forms can be used to perform particular pragmatic work (such as conveying stance and social action) and 2) norms, preferences and expectations regarding the distribution of this work vis à vis particular social identities of speakers, referents, and addressees.

She goes on to argue that we need to understand, then, (1) how particular linguistic forms can be used to perform particular pragmatic work and 
(2) what are the norms, expectations, and preferences about the distribution of this work across gender categories. Continuity in women's verbal practices across diverse situations is due to habitual gender differences in things like stance and social action (for example, confirmation checks), which carry over from situation to situation.

The Tenejapan case is a beautiful example of this, for it is the exception that proves the rule: Even when women are not being polite, characteristic female strategies of indirectness and politeness are manifested in their specch.

This suggests that, for a deeper understanding of language and gender, we need to take very detailed looks at gender behavior in different situations. One situation casts light on others, especially if one (like confrontation) is defined in opposition to the other (ordinary courtcous interaction). By looking at how gender meanings get transformed in contexts of confrontation, we can explore the complex situational variability in what spcakers, malc or femalc, arc aiming at when thcy speak. For cxample, is it cooperation, harmony, the "we" code that is being cvoked, or is the interaction one of conflict or self-defense, in the idiom of "I versus you"?

Most significantly, the Tencjapan case suggests how we might try to make sense of the widespread finding in language and gender research that women interact more cooperatively than men do, at least on the surface; that a patina of agrecment is put over women's interactions in many contexts and in different societies. With the Tencjapan women, this coopferative ethos spills over into their noncooperative discourse. The result is sarcastic cooperation and sarcastic indirectness: exploiting mutual knowlcdge and shared agreement strategies to emphasize disagreement. In Tenejapa (as well as in Japan, it has been suggested) ${ }^{11}$ this particular stance is a woman's forte, and it makes the criticism/disagreement all the more painful, as the supcrficial amicability in which it is couched adds an additional barbed element to the contrast.

Onc would hope that close attention to these situation-specific kinds of spech events will improve our understanding of how and when gender is implicated in interaction and, when it is, just how it affects women's and men's ways of speaking. Only then will we be in a position to address the more general comparative sorts of questions posed by Ochs (1992): What kinds of meanings (social, pragmatic) are women and men likely to index in their speech in different kinds of societies, and how do such gender meanings relate to the positions and the images of men and women in society?

\section{NOTES}

In previous incarnations, this chapter was given as a paper at the Australian Anthropological Society meetings in August 1981 and at seminars at the Australian National University; at Sussex University, England, in 1983; at the University of Colorado, Boulder and at the Max Planck Institute for Psycholinguistics in Nij- 
megen, Holland, in 1988. I am grateful for the many comments that improved my thinking about the issues herein addressed. The fieldwork on which this paper is based was conducted by Stephen Levinson and me in July-August 1980, when four court cases in addition to the one analyzed here were tape-recorded and filmed with Super-8 equipment, in a project funded by the Department of Anthropology, Research School of Pacific Studies, The Australian National University.

This chapter originally appeared in Discourse Processes 13(1990):1.123-141.

1. This study is pertinent not only as an exploration of language and gender, the emphasis in this chapter, but also as a contribution to the literature on the organization of courtroom speech, as contrasted with speech in other contexts (see, for example, Atkinson \& Drew 1979, Lakoff 1989), and to the recently burgeoning interest in how face-to-face confrontation is managed (for example, Goodwin \& Goodwin 1987, Haviland 1989, Grimshaw 1990).

2. The Tzeltal data cited here come from films and/or tape recordings of natural interactions in Tencjapa. Transcription conventions: Square brackets II indicate overlapping speceh; $=$ indicates speceh tied to that on the next line with no pause; dots in parentheses (. . .) indicate material omitted; a single dot in parentheses (.) indicates a micropause; numbers in parentheses, for example (1.5), indicate approximate pauses in seconds; words in parentheses () indicate sections where transcription is uncertain; an arrow $\rightarrow$ draws attention to a line of transcript under discussion. The Tzeltal transcription is roughly phonemic: $c$ represents the sound spelled in English $c h, x$ corresponds to English sh, z represents English $t s$, ? indicates a glottal stop, and 'indicates that the preceding consonant is glottalized. Speakers' initials are in parentheses when the line following is a continuation of a tum begun on a prior line. Question mark ? in translation indicates translation uncertain.

3. There are, of course, personality differences among individuals. I am describing a general cultural constraint on the mode of expression of anger, which individuals may differentially bow to.

4. I use the labels "plaintiff" and "defendant" in these restricted senses here, although these are very unsatisfactory terms insofar as they carry all the connotations of Western legal practice, which are inapplicable in the Tencjapan case. The summons-initiator, who lodges the original complaint, and the summonsrecipient, who is the object of the complaint, might well switch complainercomplainee roles in the course of the procecdings: Plaintiff might become the accused and defendent the accuser, and indeed, the original plaintiff might be the one who is hauled off to jail.

5. Despite this named style, Tzeltal speakers themselves do not categorize speech in the courtroom as different in kind from that taking place in other contexts. Conversation in Tzeltal is a form of ?ac k'op "new speech," covering all the secular and modern genres of speech (joking, conversing, word play, speechmaking), as distinct from the special genres of poko kop "ancient speech," which cover the sacred and ritual uses of words and music. The speech in a court case is a kind of 'ac k'op, with structural features similar in most respects to those of casual conversation (Payanel); it is not a specialized genre (see Stross 1974), and "explaining speech" in other contexts is also called col k'op.

6. Serious crimes under Ladino law, especially murder, are not tried in the Tencjapan court but are sent to a Ladino court in San Cristóbal. Major crimes (murder, by violence or witcheraft, and major theft) often do not come to court at 
all. The culprit flees and lies low for a while, possibly for years; then he or she may return and all may be, if not forgotten, ignored.

7. It should be noted that Tenejapan cases differ in this respect from the case reported by Nash (1970) for the nearby Tzeltal community of Amatenango, which was much more formally structured and bounded. Sec also Collier's (1973) description of Tzotzil courts in Zinacantan.

8. They also completely ignore the camera, two tape recorders, and the two foreign ethnographers in the room. At no point do their eyes meet the camera, and they appear oblivious to it. (This was not the case during our filming of casual interaction.)

9. This is even more true in the neighboring community of Zinacantan (Haviland \& Haviland 1983). There women are apparently much more circumspect about entering into court cases at all (Devereaux 1988).

10. This is particularly clear in cases where the charge is an assault on a girl's sexual reputation. In onc hearing I observed at the hamlet level, a girl who had been publicly accuscd by a woman of "wanting to marry the woman's son," produced an hour-long tirade violently protesting her innocence, outrage, and humiliation at the unjust slander. Her reputation as a "good" girl was thereby publicly reinstated, a matter of some importance in a socicty where the sullying of an unmarried girl's reputation, whether justificd or not, can provoke beatings from her father and/or brother.

11. The connection between Japanese women and ironic politeness as rudeness was suggested to me by a Japanese student at one of the seminars in which this material was presented. In Brown (1979) I illustrated Tencjapan women's ironic stance in much more detail and made the suggestion that an ironic stance is perhaps especially the ploy of the downtrodden or underprivileged.

\section{REFERENCES}

Atkinson, J. Maxwell \& Drew, Paul (1979). Order in court: The organisation of verbal interaction in judicial settings. London: Macmillan.

Brown, Pcnclope (1979). Languagc, interaction and scx roles in a Mayan communiry: A study of politeness and the position of women. Ph.D. diss., University of California, Bcrkcley.

Brown, Penelope (1980). How and why are women more polite: Some evidence from a Mayan community. In Sally McConnell-Ginet, Ruth Borker \& Nelly Furman (Eds.) Women and language in literature and society (pp. 111149). New York: Praeger.

Brown, Penelope (in/ (prits). Politeness strategies and the attribution of intentions: The case of Tzeltal irony. In Esther Goody (Ed.) Implications of a social origin for human intelligence. Cambridge: Cambridge University Press.

Brown, Penelope \& Levinson, Stephen C. (1979). Social structure, groups, and interaction. In Klaus Scherer \& Howard Giles (Eds.) Social markers in speech (pp. 291-341). Cambridge: Cambridge University Press.

Brown, Penclope \& Levinson, Stephen C. (1987). Politeness: Some universals in language usage. Cambridge: Cambridge University Press.

Collier, Jane F. (1973). Law and social change in Zinacantan. Stanford, CA: Stanford University Press. 
Devereaux, Leslie (1988). Gender difference in Zinacantan. In Marilyn Strathern (Ed.) Dealing with inequality: Analysing gender relations in Melanesia and beyond (pp. 89-111). Cambridge: Cambridge University Press.

Garfinkel, Harold (1967). Studies in ethnomethodology. Englewood Cliffs, NJ: Prentice-Hall.

Goodwin, Marjorie Harness \& Goodwin, Charles (1987). Children's arguing. In Susan Philips, Susan Steele \& Christine Tanz (Eds.) Language, gender and sax in comparative perspective (pp. 200-248). Cambridge: Cambridge University Press.

Grimshaw, Allen (Ed.) (1990). Conflict talk. Cambridge: Cambridge University Press.

Haverkate, Henk. (1988). Towards a typology of politeness strategy in communicative interaction. Multilingua 7(4):385-409.

Haviland, John B. (1989). Sure, sure: Evidence and affect. In Elinor Ochs \& Bambi Schieffelin (Eds.) Discourse and affect, Special issuc of Text 9(1):2768.

Haviland, Leslie K. \& Haviland, John B. (1983). Privacy in a Mexican village. In S. I. Benn \& G. F. Gauss (Eds.), Public and private in social life (pp. 34l361). London: Croom Helm.

Lakoff, Robin (1975). Language and woman's place. New York: Harper \&c Row. Lakoff, Robin Tolmach (1989). The limits of politeness: Therapeutic and courtroom discourse. In Sachiko Ide (Ed.) Linguistic politeness II. Multilingua 8:2-3.

McConnell-Ginet, Sally (1988). Language and gender. In Frederick J. Newmeyer (Ed.) Cambridge survey of linguistics: Vol. 4 (pp. 75-99). Cambridge: Cam. bridge University Press.

Nash, June (1970). Rhetoric of a Maya Indian court. In Estudios de cultura maya: Vol. VIII.

Ochs, Elinor (1992). Indexing gender. In Alessandro Duranti \& Charles Goodwin (Eds.) Rethinking contaxt (pp. 335-358). Cambridge: Cambridge University Press.

Philips, Susan U., Steele, Susan \& Tanz, Christine (1987). Language, gender and sex in comparative perspectipe. Cambridge: Cambridge University Press.

Strecker, Ivo (1988). The social practice of symbolization: An anthropological analysis. London: Athlone.

Stross, Brian (1974). Speaking of speaking: Tenejapan Tzeltal metalinguistics. In Richard Bauman \& Joel Sherzer (Eds.) Explorations in the ethnography of speaking (pp. 213-239). Cambridge: Cambridge University Press.

Tannen, Deborah (1987). Repetition in conversation: Toward a poetics of talk. Language, 63(3):574-605.

Tannen, Deborah (1989). Talking poices: Repetition, dialogue, and imagery in conversational discourse. Cambridge: Cambridge University Press. 